\title{
Błażej Szymankiewicz Rumuńska choroba na śmierć. Kilka uwag o hermeneutyce cielesności (na przykładzie prozy Maxa Blechera)
}

\begin{abstract}
Szymankiewicz Błażej, Rumuńska choroba na śmierć. Kilka uwag o hermeneutyce cielesności (na przykładzie prozy Maxa Blechera) [Romanian "sickness unto death". A few comments about the hermeneutics of carnality (the example of Max Blecher's prose)]. "Przestrzenie Teorii" 30. Poznań 2018, Adam Mickiewicz University Press, pp. 291-302. ISSN 1644-6763. DOI 10.14746/ pt.2018.30.15.

In the European literature and culture of the interwar period we can observe increased interest in the physicality and the process of dying. Novels which touch upon these subjects are described by some scholars and critics as "sanitarian literature". The following text is discussing the issues of the works of Max Blecher; his novel "Scarred Hearts" can be included in the circle of mentioned "sanitarian literature". Blecher's novel presents certain strategies of dealing with a terminal illness and the finiteness of human existence, as well as the alientation associated with these. The most frequently cited interpretive trail in this case is the philosophy of Kierkegaard, Jaspers and Heidegger. In the first part of the article, I refer to Blecher's biography and his reception, while in the next part I contrast selected excerpts from his novel with philosophical hermeneutics.
\end{abstract}

KEYWORDS: Max Blecher, hermeneutics of carnality, hermeneutics of dying, sanitarian literature

„Niech żyje krwista maź!” - takim zawołaniem Lawrence Durrell zakończył pierwszy z serii wielu listów do swojego pisarskiego mentora, Henry'ego Millera ${ }^{1}$. Co mógł mieć na myśli angielski pisarz? Początek lat trzydziestych $\mathrm{XX}$ wieku to w europejskiej literaturze szczególny czas, kiedy nie cichna echa zachwytów (lub potępienia) nad surrealizmem, tworzą się zręby egzystencjalizmu, a w myśli współczesnych artystów i filozofów rozpoczyna się żmudny proces dowartościowywania i zwracania coraz większej uwagi na problematykę cielesności. Cielesności rozumianej właśnie jako „krwista maź", słabej, schorowanej, zmysłowej, seksualnej i sensualnej, gnijącej i obumierającej. Nowoczesność, jak pisze Ewa Rewers, upodobała sobie naturalistyczne i turpistyczne metafory ${ }^{2}$. Proces ten zaczą się już w wieku XIX: skupienie na fizjologii, śmierci i chorobie znajdziemy w Gtodzie Knuta Hamsuna i u Baudelaire'a, który porównał Paryż do wrzodu na ciele Francji. Metaforę uprzestrzennienia ciała i toczącej go choroby spotykamy później

${ }^{1}$ H. Miller, L. Durrell, Listy 1935-1980, przeł. Z. Stanisławska, Warszawa 2001, s. 7.

${ }^{2}$ E. Rewers, Od doświadczenia po doświadczenie. „Niewinny” dotyk nowoczesności, „Teksty Drugie” 2006, nr 3, s. 47. 
między innymi u wspomnianego Millera (świat jako nowotwór) czy w $D \dot{z} u$ mie Alberta Camusa. W polskiej krytyce mówi się nieraz o „witkacowskich bebechach"3 ${ }^{3}$ trzewiach. Szczególne zainteresowanie problematyką cielesności wykazywała myśl francuska (Maurice Merleau-Ponty, Georges Bataille, André Breton), której recepcję odnajdziemy u pisarzy środkowoeuropejskich. Silne związki z zachodnioeuropejskim surrealizmem sa obecne w kulturze międzywojennej Czechosłowacji, ale także Rumunii - ówczesny Bukareszt nie bez powodu nazywano „Paryżem Wschodu”. Owe inklinacje do pisania o ciele, chorobie i śmierci w subwersywnym wydaniu zainspirowały również Maxa Blechera, rumuńskiego pisarza żydowskiego pochodzenia, którego twórczość przez dziesiątki lat pozostawała na marginesie europejskiego literaturoznawstwa. W tym przypadku wpływ na tematykę jego prozy miała przede wszystkim tragiczna biografia i silne osobiste zaangażowanie.

Blecher urodził się 8 września 1909 roku w Botoszanach, a dzieciństwo i młodość spędził w prowincjonalnym miasteczku Roman. W wieku dziewiętnastu lat wyjechał do Paryża, by studiować medycynę. Wtedy też zdiagnozowano u niego chorobę Potta - gruźlicę kręgosłupa. Sparaliżowany, ostatnią dekadę życia spędził unieruchomiony w gipsowym pancerzu, w pozycji horyzontalnej, poruszając się wyłącznie dzięki specjalnemu wózkowi inwalidzkiemu. Przebywał w różnych europejskich sanatoriach: we Francji, w Szwajcarii, na rumuńskim czarnomorskim wybrzeżu. Przy okazji przejściowego pobytu w Rumunii w roku 1934 zamieścił w braszowskim periodyku Fryzy przekłady wierszy Guillauma Apollinaire'a, Richarda Aldingtona i Shane’a Lesliego, a równocześnie opublikował własna, pisaną po francusku poezję w czasopiśmie Bretona Surrealizm w stużbie rewolucji.

W tym samym roku ukazał się również tomik jego wierszy Przezroczyste ciało, a Blecher zaczął pracować nad swym najsłynniejszym dziełem, Zdarzeniami w bliskiej nierzeczywistości. Opisał tam, jak przeżył ostatnich dziesięć lat życia: leżąc na plecach, z ciałem uwięzionym w gipsie, z kolanami zgiętymi pod ostrym kątem i cierpiąc z powodu otwartych wrzodów, z których nieustannie wyciekała ropa. Zdarzenia $w$ bliskiej nierzeczywistości ukazały się w 1936 roku, głównie dzięki wysiłkom Geo Bogzy, pisarza tego samego pokolenia, który należał wówczas do grupy artystów awangardowych.

Mimo iż stan jego zdrowia nieustannie się pogarszał, Blecher nie zaprzestał śledzenia nowoczesnej literatury światowej i sztuk plastycznych, które były mu bliskie. Korespondował między innymi z Martinem Heideggerem, André Bretonem i Salvadorem Dali, zaczytywał się w dziełach Karla Jaspersa. Regularnie zamieszczał w czasopismach rozmaite artykuły i recenzje oraz kończył swoją drugą powieść, Zabliźnione serca. Doczekał

${ }^{3}$ Zob. E. Łubieniewska, Czysta forma i bebechy, Kraków 2007. 
jej wydania: książka ukazała się w 1937 roku, ale ostatnie dzieło Blechera, Rozświetlona nora, zostało wydane pośmiertnie, dopiero w 1971 roku. Świadectwo o ostatnich dniach pisarza podaje jego przyjaciel Saşa Pană, rumuński awangardzista. Często odwiedzał chorego Blechera, który przyjmował go, jak sam mawiał, „na swym łożu śmierci”, trapiony bólami jako „żyjący pomnik cierpienia"4. Max Blecher zmarł 31 maja 1938 roku w domu swoich rodziców na obrzeżach Roman, mając niecałe dwadzieścia dziewięć lat ${ }^{5}$.

Rumuńscy krytycy dwudziestolecia międzywojennego określali najczęściej Blecherowska prozę jako odmianę psychologizmu, wówczas bardzo popularnego w literaturze rumuńskiej ${ }^{6}$. Z pisarza czyniono także przedstawiciela szeroko pojętej awangardy i surrealistę. Poza Rumunią Blecher doczekał się pewnej recepcji we Francji, głównie za sprawą znajomości z francuskimi kręgami intelektualnymi (sam doskonale znał francuski, zaczytywał się w tamtejszych czasopismach literackich, tłumaczył poezję).

W Polsce nad twórczością Blechera (jako jeden z nielicznych badaczy ${ }^{7}$ ) pochylił się poznański rumunista Zdzisław Hryhorowicz, wskazując na „powinowactwa przestrzeni” w twórczości Blechera i Brunona Schulza ${ }^{8}$. Autora Zabliźnionych serc porównywano nie tylko do drohobyczanina. Krytycy zwracali również uwagę na możliwe analogie z twórczością Roberta Walsera czy Tomasza Manna, niektórzy, między innymi Nicolae Manolescu czy Ion Negoițescu, wywodzili pisarstwo Blechera z egzystencjalizmu spod znaku Karla Jaspersa9. Dość często, zwłaszcza w Rumunii, określano go jako „rumuńskiego Kafkę” - takie stwierdzenie pojawiło się w tekście Adriana Marino ${ }^{10}$, a Nicolae Balotă pisał: „Tak jak Kafka, kolejny wielki chory człowiek literatury tego stulecia, Blecher najwyraźniej pisze wyłącznie literaturę konfesyjną"11.

U Blechera w przedziwny sposób to ciało staje się słowem, narracją umęczonego organizmu i przewrażliwionej psyche, podsycając gnostycki posmak

${ }^{4}$ Cyt. za: H. Janovská, Metafizycké autobiografie Maxe Blechera, [w:] M. Blecher, Př́hody z bezprostředního neskutečna, Zjizvená srdce, přeložila H. Janovská, Praha 1996, s. 293.

${ }^{5}$ Notę biograficzną przygotowałem na podstawie tekstu Hany Janovskej oraz informacji udostępnionych mi przez dyrektorkę Rumuńskiego Instytutu Kultury, Sabrę Daici.

${ }^{6}$ Z. Hryhorowicz, Bruno Schulz i Max Blecher: powinowactwa przestrzeni, „Balcanica Posnaniensia. Acta et studia" 2009, nr 16, s. 24.

${ }^{7}$ Jedyną komplementarną pracą dotyczącą interesującej mnie problematyki jest dysertacja doktorska Sabry Daici, zatytułowana „Czyż pod stotem, który nas dzieli, nie trzymamy się wszyscy tajnie za ręce?” Przestrzeń spotkania dwóch pisarzy: Bruno Schulz i Max Blecher. Praca została obroniona na Wydziale Filologicznym Uniwersytetu Jagiellońskiego w 2005 roku.

${ }^{8}$ Z. Hryhorowicz, dz. cyt.

${ }^{9}$ Tamże, s. 25.

${ }^{10}$ Hot black ink: modernist idiosyncrasies: Urmuz-Mateiu-Blecher-Fondane-Naum, Bucureşti 2003, s. 148.

${ }^{11}$ Tamże (tłum. moje - B.Sz.). 
tej literatury. Ciało jest przy tym pułapka, więzieniem, ale wyzwolenie się z niego wcale nie musi oznaczać zbawienia. Obietnica transcendencji pozostaje zawieszona, a schorowane ciało stanowi główny bodziec i podstawę aktu twórczego: Blecher pisał o tym w dzienniku sanatoryjnym, Rozświetlonej norze, porównując pisanie do krążenia krwi - dla tego pisarza „żyć oznacza napraw dę pisać", stwierdza Hryhorowicz ${ }^{12}$.

Niewątpliwe największa „obsesja”, naczelnym tematem prozy Blechera jest materia i cielesność. Żaneta Nalewajk w swoim studium $W$ strone perspektywizmu zauważa, iż

[...] predylekcja do „mówienia o ciele” i „pisania ciałem” są znaczące: nie maja charakteru czysto ornamentacyjnego czy przypadkowego. Przeciwnie, to punkt wyjścia do sformułowania autorskiej wizji człowieka i rzeczywistości, powiązanej z koncepcją kultury, rozumieniem tożsamości, wartości czy wreszcie poznania. Uważam, że na kartach dzieł prozatorskich [...] za pośrednictwem aktualizacji kategorii ciała manifestują się oraz znajdują artystycznie najdoskonalszy wyraz kluczowe problemy epoki modernizmu ${ }^{13}$.

Z kolei Mieczysław Dąbrowski tak opisuje problematykę artystycznego rozumienia choroby w epoce modernizmu:

Choroba jest zatem sposobem poznawania lub: lepszego poznawania świata. Cierpienie wyszlachetnia wrażliwość nerwów, wzmaga doznania, odwraca myśl od świata zewnętrznego i kieruje ją w stronę wnętrza, ku myśli i metafizyce. Człowiek chory, zwłaszcza gruźlik, którego nerwy wyczulone są w sposób szczególny ze względu na ciagłe stany podgorączkowe, ostrzej i dobitniej odbiera bodźce idące ze świata zewnętrznego. Artysta cierpi też głębiej niż inni, ponieważ jako natura wrażliwsza ex definitione lepiej odczuwa różnicę między stanem pożądanym a osiaganym, wyraźniej odbiera upływ czasu, ostrzej rozróżnia teraźniejszość, przeszłość i przyszłość. Każde pragnienie rodzi ból, ponieważ na ogół kończy się rozczarowaniem. Przy tym choroba może się objawić jako choroba ciała (bardzo w dziewiętnastym wieku rozpowszechniona gruźlica, w dwudziestym wieku rak) albo jako choroba duszy (melancholia, obniżenie nastroju, niechęć do życia, nerwice itp.) ${ }^{14}$.

Blecher reprezentuje zarówno chorobę ciała (gruźlica kręgosłupa), jak i ducha, gdyż obie te sfery są w jego twórczości ściśle ze sobą powiązane. Pisarz traktuje tworzenie literatury jako strategię radzenia sobie z cierpieniem (to dość typowy wątek środkowoeuropejski - por. biografia i autobiografia Thomasa Bernharda ${ }^{15}$ ). Zasadne wydaje mi się nazwanie Blechera patolo-

${ }^{12}$ Z. Hryhorowicz, dz. cyt., s. 34.

${ }^{13}$ Ż. Nalewajk, W stronę perspektywizmu. Problematyka cielesności w prozie Brunona Schulza i Witolda Gombrowicza, Gdańsk 2010, s. 12.

${ }^{14}$ M. Dąbrowski, Dekadentyzm wspótczesny. Gtówne idee, motywy i postawy modernistyczne w polskiej i niemieckojęzycznej literaturze XX wieku, Izabelin 1996, s. 99.

${ }^{15}$ Zob. T. Bernhard, Autobiografie, przeł. S. Lisiecka, Kraków 1998. 
giem i pato-grafem, to znaczy twórca, który walczy z pato ${ }^{16}$ (cierpieniem, choroba) przy pomocy logosu. Blecher jako obłożnie chory człowiek, martwy za życia, manekin unieruchomiony przez dekadę w gipsie, nadaje sens $d z o e$ (biologicznemu życiu) poprzez logos, usensowienie życia w chorobie (widmo nieuchronnej śmierci), przemianę w egzystencję, bio-grafię. Materia i cielesność staja się dla autora Zabliźnionych serc tekstem i pre-tekstem do pisania. Twórczość pisarza ma ogromny potencjał hermeneutyczny - poprzez przekształcanie nieludzkiego w ludzkie (Schulz nazwałby to „zhumanizowanie mnie do ludzkich obszarów"17) dokonuje się próba interpretacji, rozumienia, wyjaśniania (problem ze skonstruowaniem spójnej tożsamości, poszukiwanie odpowiedzi na pytania o to, kim jestem, czym i jaki jest świat etc.). Obsesja „materii” nie dotyczy, rzecz jasna, jedynie materii żywej - Blecher zwracał również uwagę na to, że chore i niepełno(s)prawne mogą być także z pozoru martwe rekwizyty czy przestrzenie, których obecność i świadomość ich natury - co ważne - determinuje stan psychofizyczny człowieka.

Blecherowski narrator doświadcza nieustannego napięcia między rzeczywistością a nierzeczywistością ${ }^{18}$, a ten ontologiczny konflikt staje się pożywką dla całej twórczości pisarza. Dla Blechera charakterystyczna jest swoista antropomorfizacja przestrzeni i rzeczywistości, kształtowanie jej na obraz ludzkiej anatomii i fizjonomii. Aleksandra Ubertowska, pisząc o prozie Brunona Schulza, stwierdziła, że należy w jej przypadku mówić nie o radykalnej antropomorfizacji, lecz o „somatyzacji świata” ${ }^{19}$. To samo stwierdzenie zaskakująco zgodnie koresponduje z twórczością rumuńskiego autora. Swoiste „przedłużanie” ciała i zmysłów jest wspólne obu pisarzom - Blecher był do tego zmuszony przez chorobę. Wskazuje na to klamra

${ }^{16}$ Patologia: gr. пá日os „pathos” - cierpienie, - גoyia „-logia” - przyrostek tworzacy rzeczowniki oznaczające gałęzie nauki. Michał Paweł Markowski napisał: „Słowo patologia użyte przez Schulza nie powinno nas zmylić dzisiejszymi, głównie negatywnymi konotacjami. Odsyła ono do greckiego źródła i oznacza szeroko pojętą «uczuciowość i «wrażliwość». Pathos to - jak podaja greckie słowniki - namiętność i emocja (i tak pathos rozumiany jest w ramach paradygmatu romantyczno-modernistycznego), ale także, w bardziej źródłowym znaczeniu, «to, co się komuś przydarza». W tym znaczeniu doświadczenie literackie jest «patologiczne», bo pokazuje, że człowiek dzięki literaturze dotyka "głębi», które "zagrażają duszy» i które wystawiają ją w na niesłychaną i nieprzewidywalną próbę". M.P. Markowski, Polska literatura nowoczesna. Leśmian, Schulz, Witkacy, Kraków 2007, s. 50 (wyróżn. - M.P.M.).

${ }^{17}$ W liście do Witolda Gombrowicza (B. Schulz, Księga listów, wstęp i oprac. J. Ficowski, Kraków 1975, s.72).

${ }^{18}$ O owym napięciu pisał Jerzy Franczak, w kontekście Gombrowicza i Schulza, zob. J. Franczak, Poszukiwanie realności. Światopoglad polskiej prozy modernistycznej, Kraków 2007, s. 311.

${ }^{19}$ A. Ubertowska, Cielesna retoryka Brunona Schulza, [w:] Między słowem a ciałem. Materiaty $z$ IV Sesji Naukowej z cyklu „Świat jeden, ale nie jednolity”, red. L. Wiśniewska, Bydgoszcz 2001, s. 245. 
kompozycyjna zastosowana w Zdarzeniach: narrator, zamknięty w pokoju, rozpoczyna swoje rozważania o tożsamości od wpatrywania się „w stały punkt na ścianie" ${ }^{20}$. Ta sytuacja powraca w zakończeniu powieści, co może sugerować, że bohater zamknięty był przez cały czas, a narracja to tak naprawdę reminiscencja, sen lub halucynacje. Blechera nie zajmuje kwestia myślenia o ciele czy wartościowania go, ale sposób, w jaki cało jest „pisane”. Jego strategię pisarską można określić jako „ciałopisanie”. Ciało staje się, zgodnie ze światopoglądem wyznaczonym przez nowoczesność krytyczna, sfera graniczna, polem dialektycznych starć, cechuje się nieusuwalna dwuznacznością. „Gra życia i śmierci w stającym się ciele jest napięciem między tożsamością oraz różnica, a zarazem sprzężeniem i współistnieniem przeciwieństw" - twierdzi Nalewajk ${ }^{21}$.

Blecher rozpoczyna Zdarzenia w bliskiej nierzeczywistości tymi słowami:

[...] zdarza mi się niekiedy, że nie wiem już, ani kim jestem, ani gdzie się znajduję. Odczuwam wtedy brak mojej tożsamości z oddalenia, jakbym stał się, przez chwilę, całkowicie obca osoba. Ta abstrakcyjna istota i moja realna postać rywalizują o moje przekonanie. (Zd 7)

Uporczywe pytanie „kim właściwie jestem?” żyje wtedy we mnie jak całkiem nowe ciało, które urosło w moim wnętrzu z obcą mi skórą i organami. Odpowiedzi na nie domaga się jasność głębsza i istotniejsza niż jasność mojego umysłu. Wszystko, co może burzyć się w moim ciele, burzy się, miota i buntuje mocniej i żywiej niż w codziennym życiu. Wszystko domaga się błagalnie rozwiązania. (Zd 8)

Zaskakujące rezultaty mogłaby przynieść próba lektury Blechera odwołująca się do „myśli słabej”. „Rumuńska kruchość bytu” (o której pisał Andrzej Zawadzki w kontekście filozofii Constantina Noiki ${ }^{22}$ ) objawia się tutaj w dwójnasób: chory, niepełnosprawny autor zwraca uwagę na słaba, kruchą rzeczywistość, tworzy narratora, który ulega - jak sam to nazywa „kryzysom”, jest słaby fizycznie, ale także zdewastowany psychicznie: zadaje „typowo” hermeneutyczne pytania o podstawy bytu. Sam podaje w wattpliwość własną tożsamość i charakter otaczającej go rzeczywistości, która często określa jako kruchą, sztuczną i fasadową. Noika zwracał uwagę, że myśl rumuńska, w przeciwieństwie do zachodniej, interesowała się „światem niskim" ${ }^{23}$, rozpadem i cielesnościa. Ślady takiej filozofii odnajdziemy w prozie Blechera. Warto zwrócić także uwagę na tytuł i związaną z nim Blecherowską koncepcję czasu, sugerujące zdarzeniowość, przygodność egzystencji, co także koresponduje z niektórymi założeniami rumuńskiej

${ }^{20}$ M. Blecher, Zdarzenia w bliskiej nierzeczywistości, przeł. J. Kornaś-Warwas, Sejny 2013, s. 7. Dalsze cytaty oznaczam w tekście skrótem Zd wraz z numerem strony.

${ }^{21} \dot{Z}$. Nalewajk, dz. cyt., s. 47.

22 A. Zawadzki, Literatura a myśl słaba, Kraków 2010, s. 29.

${ }^{23} \mathrm{Za}$ : tamże, s. 43. 
myśli słabej. Blecherowscy bohaterowie, niejako bezradni wobec zastanego świata, to często ludzie chorzy i ułomni, którzy - tak jak człowiek w projekcie Noiki - pochylają się równocześnie nad ułomnym światem i poszukuja możliwości współodczuwania z nim ${ }^{24}$. Zostaje to zarysowane w Zdarzeniach, ale w pełni wybrzmi dopiero w kolejnym dziele autora.

Niezwykle często w Zdarzeniach pojawia się motyw snu, utraty przytomności, maligny, halucynacji. To kolejny, oczywisty trop surrealistyczny, choć nie tylko - funkcjonuje on także jako swego rodzaju zapowiedź śmierci i możliwość chwilowej ulgi dla cierpiącego ciała, uspokojenia zmysłów. Sen to najczęściej przywoływany egzystencjalny komponent doświadczenia śmierci ${ }^{25}$.

Jednym z fundamentalnych tematów prozy Blechera jest proces umierania i zmagania się człowieka z własną śmiertelnością. Filozoficzne problematyzowanie ludzkiej skończoności to z pewnościa „pożywka” dla interpretacji hermeneutycznej, biorąc pod uwagę niezwykle ważną rolę czasowości w hermeneutyce filozoficznej. Piotr Jakubowski twierdzi, że myśl hermeneutyczna „powraca do swoich źródeł” właśnie w namyśle nad „tajemnica śmierci”"26. Jednak tym, co hermeneutyczne spojrzenie może uchwycić, jest proces umierania starzejącego się lub chorego ciała, nie zaś stan samej śmierci. Ów proces staje się centralnym motywem drugiej powieści Blechera, Zabliźnionych serc. Zalicza się ona do kręgu „literatury sanatoryjnej”, charakterystycznej dla okresu międzywojennego, o czym pisał między innymi Jens Herlth w tekście Stodko-gorzkie heterotopie ${ }^{27}$. Niektórzy krytycy porównują druga powieść Blechera do Czarodziejskiej góry - jej fabuła toczy się w sanatorium Berck sur Mer nad kanałem La Manche (w którym to Blecher przebywał naprawdę).

Pisarz opisuje umieranie książkowych pacjentów, ale mierzy się także z własną śmiertelną choroba, pośrednio opisując ją poprzez postać protagonisty, Emanuela. Ekstatyczność i afekty, silnie obecne w tej prozie, to manifestacja pragnienia transcendencji, wykroczenia „poza siebie” i odżegnania od siebie wizji nieuchronnej śmierci lub nieuleczalnej choroby. Blechera interesują Jaspersowskie sytuacje graniczne, które - w moim przekonaniu - są fundamentem twórczości środkowoeuropejskich pisarzy nowoczesnych w ogóle.

${ }^{24}$ Tamże, s. 32.

${ }^{25}$ Zob. P. Jakubowski, Hermeneutyka umierania, „Zeszyty Naukowe Centrum Badań im. Edyty Stein" 2012, nr 9.

${ }^{26}$ Tamże, s. 97.

${ }^{27}$ Zob. J. Herlth, Stodko-gorzkie heterotopie. Bruno Schulz i „tekst sanatoryjny” $w$ europejskiej literaturze okresu międzywojennego, „Wielogłos. Pismo Wydziału Polonistyki UJ” 2013, nr 2(16). 
Jak wspomniałem, rumuńskiego pisarza zajmuje kwestia radzenia sobie z cierpieniem schorowanego ciała: bardziej niż sama śmierć interesuje go powolny proces pogłębiania się choroby. Blecher prezentuje szerokie pole manewru i stawia czytelnika przed arcyciekawa sytuacja hermeneutyczna, gdyż w Zabliźnionych sercach umieszcza wielu bohaterów cierpiących na tę samą jednostkę chorobową w zamkniętej przestrzeni uzdrowiskowego miasteczka i sanatorium. Przedstawia sytuacje egzystencjalne wielu postaci naraz: $\mathrm{z}$ jednej strony sa one jednakowe, dotyczą oczekiwania na śmierć lub uzdrowienie, z drugiej zaś każda postać obiera (mniej lub bardziej świadomie) inna „, strategię”: szaleństwo i apatię (Isa), czarny humor i pozorny dystans (Quitonce), miłość i seks (Emanuel, Solange) etc.

Blecherowscy kuracjusze, częściowo unieruchomieni przez gruźlicę kręgosłupa, starają się toczyć normalne życie, co prowadzi do masowego samooszustwa. Zachowanie pozorów nadaje resztki sensu absurdalnym okolicznościom, w których człowiek nie może funkcjonować tak, jak przed popadnięciem w chorobę, i nie jest nawet zdolny używać części swojego ciała zgodnie z ich przeznaczeniem. Choroba utrudnia stosunki płciowe, życie towarzyskie, w wielu przypadkach staje się przyczyną depresji i wykluczenia. Jest to wykluczenie radykalne, którym byli pacjenci pozostają „zarażeni” nawet po opuszczeniu sanatorium i po całkowitym (fizycznym) wyleczeniu. Ernest, jeden z pacjentów, stwierdza:

[...] Berck to nie jest miasto chorych. To niezmiernie subtelna trucizna. Wsącza się prosto w krew. Ten, kto tu trochę pożył, nie znajdzie już sobie miejsca nigdzie na świecie. Ty też to poczujesz pewnego dnia. Wszyscy tutejsi kupcy, lekarze, aptekarze, a nawet sanitariusze... To wszystko dawni kuracjusze, którzy nie potrafili żyć gdzie indziejej.

Co ja takiego mogę robić w normalnym życiu? Co zaskakującego, niezwykłego może mnie jeszcze spotkać? Będę mył codziennie zęby, jadł obiad, a wieczorem pił kawę z mlekiem, bez względu na to, czy zdarzy się gdzieś katastrofa kolejowa, czy umrze mi ktoś z rodziny. Ciagle będę mył zęby, siedział przy stole... To ciągle będę ja. Rozumiesz? Rozumiesz, jakim przeraźliwie monotonnym zwierzęciem się stanę? [...] Kto raz został wyrwany z życia i miał wystarczająco dużo czasu i spokoju, aby zadać sobie to jedno zasadnicze pytanie o jego sens - pozostanie zatruty na zawsze... Oczywiście świat będzie istniał dalej, ale ktoś starł już gąbką z rzeczy ich znaczenie ${ }^{29}$...

Doświadczenie choroby, zagrożenie śmiercia, niebytem oraz konfrontacja z własną skończonością odbijają się niezmywalnym piętnem na życiu kuracjuszy. Jednym z ciekawszych przypadków choroby w powieści jest sytuacja młodej kobiety, Isy, która aż do swojej przedwczesnej śmierci

\footnotetext{
${ }^{28}$ M. Blecher, Zabliźnione serca, przeł. T. Klimkowski, Warszawa 2014, s. 79.

${ }^{29}$ Tamże, s. 121.
} 
łudzi się, że jej stan się poprawi i w końcu popada w chorobę psychiczną. Dziewczyna wypowiada słowa, które ujawniaja koncepcję powieściową Blechera i pojmowanie przez niego życia w chorobie:

Wiesz, co to jest w medycynie „zabliźniona tkanka”? To ta sina i pomarszczona skóra, która tworzy się na zagojonej ranie. To prawie normalna skóra, tyle że niewrażliwa na zimno, na ciepło i na dotyk... [...] Widzisz, serca nas, chorych, tyle już otrzymały w życiu ciosów nożem, że stały się taką właśnie zabliźnioną tkanką... Niewrażliwą na zimno... na ciepło... i na ból... Niewrażliwa, siną i stwardniała ${ }^{30} \ldots$

Blecherowskie sanatorium jawi się jako obóz koncentracji ludzi podwójnie wykluczonych: $\mathrm{z}$ jednej strony przez otoczenie z zewnątrz, stygmatyzujace chorych z powodu cielesnych, widocznych oznak choroby, a z drugiej strony są to ludzie o „zabliźnionych sercach”, ze stygmatami „wewnętrznymi”, które determinuja ich egzystencję. Ta sytuacja graniczna, trudna do zrozumienia dla człowieka zdrowego, mającego sprawne ciało i niezastanawiającego się nad skończonościa, stanowi hermeneutyczny ape ${ }^{31}$, który może pobudzić czytelnika do poszukiwania sensu w cierpieniu, zrozumienia i wypracowania współczucia, choć myślę, że polskie słowo „współczucie”32 nie oddaje w pełni znaczenia takiej interpretacji. Angielskie (o łacińskim źródłosłowie) sformułowanie compassion, które możemy rozwinąć do postaci common passion oznaczać może wspólną pasję, ale także namiętność i mękę. Zawiera się w nim całe spektrum emocji, o które chodzi Blecherowi. Cierpienie, rozerotyzowanie, żal, melancholia i empatia tworza konglomerat zachowań i stanów, w które popadają bohaterowie Zabliźnionych serc. Blecher zdaje się stawiać kontrowersyjne tezy i pytania, które stoją w opozycji do Husserlowskiego „wczucia się”, istnienia intersubiektywnie doświadczanej rzeczywistości ${ }^{33} \mathrm{w}$ przypadku sytuacji granicznych - czy człowieka chorego może zrozumieć tylko i wyłącznie inny chory, cierpiący na te same przypadłości, podobne bóle i niepełnosprawność? Czy istnieje szczególna solidarność między rekonwalescentami i czy jedynąrzeczą tworzacca zręby jakiejkolwiek wspólnoty jest wzajemne cierpienie w chorobie? I wreszcie, po Kierkegaardowsku, czy śmierć jest zjawiskiem, które należy egzystencjalnie antycypować, czy może nikt nie jest w stanie jej doświadczyć i pojać w ogóle ${ }^{34}$ ? Blecher sprzeciwia się kartezjańskiemu „obojętnemu

30 Tamże, s. 127.

${ }^{31}$ P. Dybel, Oblicza hermeneutyki, Kraków 2012, s. 45.

${ }^{32}$ Być może lepszym słowem w tym przypadku byłoby „współodczuwanie”.

${ }^{33}$ U. Górska, W poszukiwaniu tożsamości Europy Środkowej: przypadek bohatera galicyjskiego, Warszawa 2012, s. 110.

${ }^{34}$ Zob. J.A. Prokopski, Śmierć jako misterium ludzkiej skończoności, [w:] tegoż, Egzystencja i tragizm. Dialektyka ludzkiej skończoności, Kęty 2007. 
zaangażowaniu"35 (które samo w sobie jest pojęciem oksymoronicznym), pokazując między innymi na przykładzie postaci Quitonce'a, że w obliczu śmiertelnej choroby pseudostoicka postawa skazana jest na porażkę, a empatia i zrozumienie są wynikiem nie samych intelektualnych procesów, ale zaangażowania cielesnego, „całym sobą”.

„Nie potrzebujemy hermeneutyki, ale erotyki sztuki” - napisała Susan Sontag w słynnym tekście Przeciw interpretacji ${ }^{36}$. Z kolei Paweł Dybel zastanawiał się, czy „hermeneutyka jest sexy”" ${ }^{37}$. Myślę, że hermeneutyka wręcz powinna interesować się seksualnością i cielesnościa, ale nie w takim rozumieniu, w jakim widzi to Dybel, ironicznie (choć mało zabawnie) oskarżając współczesnych badaczy o ślepe podążanie za modą. Nie ma też zbyt wielkiej dychotomii między hermeneutyką i erotyka, jak chciałaby tego Sontag. Już w 1981 roku Jan Błoński stwierdził, że:

[...] u początków badania tekstu stoi zawsze romans z tekstem. I ten romans zaczyna się od fascynacji niezrozumiałym (choć „niezrozumiałość” może objawiać się na rozmaitych poziomach tekstu, także wtedy, kiedy znaczenia zdają się na pierwszy rzut oka przeźroczyste). Zaczyna się od bolesnego poczucia odtrącenia czy wykluczenia z czyjegoś piękna, z czyjejś prawdy ${ }^{38}$.

Ta „fascynacja niezrozumiałym” jest doświadczeniem z krwi i kości hermeneutycznym, leżacym u podstaw interpretacji w duchu hermeneutyki egzystencjalnej.

Proza Maxa Blechera, co starałem się wykazać w powyższym tekście, ma niebywały potencjał interpretacyjny. Obrazuje Heideggerowskie Sein-zum-Tode, może być rozpatrywana w kategoriach hermeneutycznej myśli słabej, a jej tematyka, dotykająca możliwości przekraczania ograniczeń skorupy schorowanego ciała i filozoficznego rozważania nad ludzka skończonościa, mogłaby zostać potraktowana jako preludium do namysłu posthumanistycznego. Również badacze zajmujący się zwrotami etycznym, afektywnym i somatycznym znaleźliby w tej twórczości wiele fragmentów wartych opracowania i pogłębionej refleksji. Blecher zrealizował surrealistyczny postulat z Nadji Bretona, który napisał „Albo Piękno będzie KONWULSYJNE, albo nie będzie go wcale" ${ }^{39}$. Nie chodzi oczywiście o piękno rozumiane konserwatywnie jako kategoria estetyczna. „Piękno jest choro-

${ }^{35}$ Ch. Taylor, Źródła podmiotowości. Narodziny tożsamości nowoczesnej, przeł. M. Gruszczyński, O. Latek, A. Lipszyc, A. Michalak, A. Rostkowska, M. Rychter, Ł. Sommer, Warszawa 2010, s. 283.

${ }^{36}$ S. Sontag, Przeciw interpretacji i inne eseje, przeł. M. Pasicka, A. Skucińska, D. Żukowski, Kraków 2012, s. 72.

${ }^{37}$ P. Dybel, dz. cyt., s. 70.

38 J. Błoński, Romans z tekstem, Kraków 1981, s. 20.

${ }^{39}$ A. Breton, Nadja, przeł. J. Waczków, Kraków 1993, s. 57. 
ba" - twierdzi Schulzowski Ojciec, zaś Blecher dopowiada: a choroba jest pięknem - ponieważ prowadzi do rozregulowania zmysłów, pobudza pokłady empatii i twórczości, stawia niewygodne pytania o sens cierpienia i śmierci, budzi odrazę i początkowe niezrozumienie, wyparcie, które należy hermeneutycznie przepracować; Rumuński literat dowartościowuje problematykę cielesności i poświadcza, że sprawy często uważane za „nieludzkie” są arcyciekawe i arcyważne dla humanistyki.

Max Blecher to jeden z tych pisarzy, których cechowało przenikliwe, buntownicze spojrzenie na rzeczywistość. To artysta, który odrzuca kondycję „zwykłego widza”, a zamiast niej przyjmuje intymna, rozedrganą perspektywę, zanurzając swoje macki w dostrzegalnym świecie, aby przebudować i wymyślić go na nowo. Blecher stara się uciec od tyranii materii, która narzuca się ludzkiej percepcji. Dlatego używa retoryki ciała i zmysłów. Obciąża swoje pisarstwo materialnością ciała, tak jak ciało jest obciążone niematerialnością języka. Rezultatem są zmysłowe, niemal erotyczne oględziny człowieczej kondycji w poszukiwaniu afektów i poczucia wspólnoty, a wszystko to pisarz przedstawia za pomocą rozbrajająco szczerej narracji, snutej przy udziale nieskrępowanej wyobraźni.

\section{BIBLIOGRAFIA}

Bernhard Th., Autobiografie, przeł. S. Lisiecka, Kraków 1998.

Blecher M., Zabliźnione serca, przeł. T. Klimkowski, Warszawa 2014.

Blecher M., Zdarzenia w bliskiej nierzeczywistości, przeł. J. Kornaś-Warwas, Sejny 2013. Błoński J., Romans z tekstem, Kraków 1981.

Breton A., Nadja, przeł. J. Waczków, Kraków 1993.

Dąbrowski M., Dekadentyzm wspótczesny. Główne idee, motywy i postawy modernistyczne w polskiej i niemieckojęzycznej literaturze XX wieku, Izabelin 1996.

Dybel P., Oblicza hermeneutyki, Kraków 2012.

Franczak J., Poszukiwanie realności. Światopoglad polskiej prozy modernistycznej, Kraków 2007.

Górska U., W poszukiwaniu tożsamości Europy Środkowej: przypadek bohatera galicyjskiego, Warszawa 2012.

Herlth J., Stodko-gorzkie heterotopie. Bruno Schulz i „tekst sanatoryjny” w europejskiej literaturze okresu międzywojennego, „Wielogłos. Pismo Wydziału Polonistyki UJ” 2013, nr 2(16).

Hot blackink: modernist idiosyncrasies: Urmuz - Mateiu - Blecher - Fondane - Naum, Bucureşti 2003.

Hryhorowicz Z., Bruno Schulz i Max Blecher: powinowactwa przestrzeni, „Balcanica Posnaniensia. Acta et studia" 2009, nr 16.

Jakubowski P., Hermeneutyka umierania, „Zeszyty Naukowe Centrum Badań im. Edyty Stein” 2012, nr 9. 
Janovská H., Metafizycké autobiografie Maxe Blechera, [w:] M. Blecher, Př́hody z bezprostředního neskutečna, Zjizvená srdce, přeložila H. Janovská, Praha 1996.

Łubieniewska E., Czysta forma i bebechy, Kraków 2007.

Markowski M.P., Polska literatura nowoczesna. Leśmian, Schulz, Witkacy, Kraków 2007.

Miller H., Durrell L., Listy 1935-1980, przeł. Z. Stanisławska, Warszawa 2001.

Nalewajk Ż., W stronę perspektywizmu. Problematyka cielesności w prozie Brunona Schulza i Witolda Gombrowicza, Gdańsk 2010.

Prokopski J.A., Śmierć jako misterium ludzkiej skończoności, [w:] J.A. Prokopski, Egzystencja i tragizm. Dialektyka ludzkiej skończoności, Kęty 2007.

Rewers E., Od doświadczenia po doświadczenie. „Niewinny” dotyk nowoczesności, „Teksty Drugie" 2006, nr 3.

Schulz B., Księga listów, wstęp i oprac. J. Ficowski, Kraków 1975.

Taylor Ch., Źródła podmiotowości. Narodziny tożsamości nowoczesnej, przeł. M. Gruszczyński, O. Latek, A. Lipszyc, A. Michalak, A. Rostkowska, M. Rychter, Ł. Sommer, Warszawa 2010.

Ubertowska A., Cielesna retoryka Brunona Schulza, [w:] Między słowem a ciałem. Materiały z IV Sesji Naukowej z cyklu „Świat jeden, ale nie jednolity”, red. L. Wiśniewska, Bydgoszcz 2001.

Zawadzki A., Literatura a myśl słaba, Kraków 2010. 